\title{
IMPLEMENTASI ALGORITMA FISHER-YATES DAN FUZZY TSUKAMOTO DALAM GAME KUIS TEBAK NADA SUNDA BERBASIS ANDROID
}

\author{
Imam Haditama ${ }^{1}$,Cepy Slamet ${ }^{2}$, Deny Fauzy Rahman ${ }^{3}$ \\ ${ }^{1,2,3}$ Jurusan Teknik Informatika, Fakultas Sains dan Teknologi \\ Universitas Islam Negeri Sunan Gunung Djati Bandung \\ Jl. A.H. Nasution 105, Bandung 40614 Indonesia \\ 1'imamhaditama@gmail.com, ${ }^{2}$ cepy.slamet@uinsgd.ac.id, ${ }^{3}$ deny.fauzy@uinsgd.ac.id
}

\begin{abstract}
ABSTRAK-Titi laras merupakan tangga nada yang digunakan pada jenis alat musik karawitan (gamelan) yang merupakan salah satu seni kebudayaan Jawa Barat. Karena kesenian merupakan salah satu unsur budaya yang bersifat universal, maka kesenian tersebut perlu dilestarikan.FisherYates merupakan teknik pengacakan pada soal sehingga soal yang keluar akan berbeda dan bisa dihasilkan tanpa pengulangan dan duplikasi. Fuzzy Tsukamoto merupakan metode yang digunakan dalam pengambilan keputusan untuk menentukan skor pada akhir kuis. Untuk menentukan berapa nilai tertinggi dalam kuis adalah dengan cara menghitung $x=$ waktu dan $x=$ nilai, proses perhitungan dilakukan dengan cara menghitung variabel-varibel Fuzzy Logic yang telah ditentukan. Dari penelitian ini dapat ditemukan bahwa Fisher-Yates mampu menentukan solusi pengacakan yang tidak berganda dan pengacakan objek yang variatif. Fuzzy Tsukamoto memiliki akurasi yang cukup baik antara perhitungan berdasarkan sistem dan perhitungan secara manual, meskipun tidak menunjukan hasil yang $100 \%$ sama pada masing-masing perhitungan. Rentan nilai antara perhitungan sistem dengan perhitungan manual mempunyai rentan yang berbeda pada setiap nilainnya.
\end{abstract}

Kata kunci: Titi Laras, Fisher-Yates, Fuzzy Tsukamoto, Aplikasi Android.

\section{PENDAHULUAN}

Kebudayaan Sunda termasuk salah satu kebudayaan tertua di Nusantara. Kebudayaan
Sunda yang ideal kemudian sering kali dikaitkan sebagai kebudayaan masa Kerajaan Sunda. Kebudayaan Sunda juga merupakan salah satu kebudayaan yang menjadi sumber kekayaan bagi bangsa Indonesia yang dalam perkembangannya perlu dilestarikan [1]. Salah satu dari kebudayaan tersebut adalah titi laras atau tangga nada sunda.

Permasalahan yang terjadi dalam bidang kesenian di antaranya pergeseran selera masyarakat, sebagian besar masyarakat seleranya mulai beralih pada seni modern atau juga karena kesenian-kesenian tradisional yang ada dinilai masih dirasakan terdapat kekurangan-kekurangan dibanding seni modern yang mulai melanda masuk desa [2]. Terjadinya pergeseran-pergeseran terhadap kesenian tradisional berhubungan dengan adanya perkembangan pengetahuan dan teknologi. Generasi muda menghendaki pergeseran secara modern sesuai dengan kehidupan zamannya. Titi laras merupakan tangga nada yang digunakan pada jenis alat musik karawitan (gamelan) yang merupakan salah satu seni kebudayaan Jawa Barat. Karena kesenian merupakan salah satu unsur budaya yang bersifat universal, maka kesenian tersebut perlu dilestarikan.

Dilihat dari permsalahan diatas maka, solusi permasalah tersebut dengan membuat game yang dapat menjadi media pembelajaran mengenai titi laras atau tangga nada sunda pada beberapa jenis alat musik karawitan yang merupakan alat musik tradisional Indonesia dari daerah Jawa Barat. Pembuatan permainan tebak nada sunda tersebut diharapkan semua orang atau setidaknya dapat membantu para siswa/i ataupun mahasiswa/i yang sedang menjalani studi di jurusan seni budaya karawitan dapat 
mempelajari dan memberikan informasi tentang titi laras atau tangga nada sunda melalui permainan ini. Permainan titi laras ini diharapkan bisa mengenalkan salah satu warisan budaya Indonesia yaitu titi laras atau tangga nada sunda. Selain itu perimainan ini bertujuan untuk melatih kepekaan pendengaran seseorang terhadap nada-nada dari beberapa alat musik karawitan tersebut, sehingga membantu untuk lebih cepat dan mudah mempelajari nadanada tersebut tanpa harus membawa semua alat musiknya.

Terdapat berbagai macam algoritma pengacak atau shuffling algorithms untuk memberikan teknik pengacakan pada soal sehingga soal yang keluar akan berbeda dan bisa dihasilkan tanpa pengulangan dan duplikasi [16]. Salah satu diantaranya adalah Fisher-Yates shuffle (diambil dari nama Ronald Fisher dan Frank Yates) atau juga dikenal dengan nama Knuth shuffle (diambil dari nama Donald Knuth). Algoritma ini menghasilkan suatu permutasi acak secara berurut sehingga pertanyaan yang telah muncul tidak akan muncul lagi di sesi yang sama sehingga membuat permainan tidak membosankan dan userakan lebih tertantang untuk memainkan permainan tersebut. Pada tahapan akhir terdapat skor untuk penilaian apakah user dapat menghasilkan skor tertinggi atau tidak, pada proses ini menggunakan algoritma Fuzzy.Metode yang akan digunakan dalam pengambilan keputusan untukmenentukan skor pada akhir kuis adalah metode Tsukamoto. Metode ini dipilih karenasetiap konsekuen pada aturan yang berbentuk IF-THEN direpresentasikan denganhimpunan fuzzy dengan fungsi keanggotaan yang monoton. Sebagai hasilnya,output dari setiap aturan diberikan secara tegas berdasarkan $\alpha$, kemudian diperoleh hasil akhir dengan menggunakan ratarata terpusat [17].

Saatinisebagianbesar orang mulaiberalihmenggunakanteknologismartphone .Salah satusmartphone yang banyakdigunakanadalahdevice Android.Banyak Developer beralihkedevice Android untukmengembangkanaplikasi

Android.Berbagaiaplikasi yang telahdikembangkanpada device Android dapat dimanfaatkan untukmemudahkanpekerjaansehari-

hari.Tercatatpadags.statcounter.compengguna

Android di Indonesia sejakakhirtahun 2013 sampaibulan Meitahun 2014mencapai 57.52\% [5].

Pesatnyaperkembangan penggunaan smarphone android saat ini, tentu dengan aplikasi mengenai game tebak tangga nada sunda berbasis Android akan memudahkan pengguna dalam mempelajari tangga nada sunda dari beberapa alat musik gamelan sunda.Dengan latar belakang tersebut maka pada penulisan ini diangkatlah pembelajaran titi laras atau tangga nada sunda untuk dikemas menjadi sebuah permainan yang berjudul "IMPLEMENTASI ALGORITMA FISHER-YATESDAN FUZZYTSUKAMOTODALAM GAMEKUIS TEBAK TANGGA NADA SUNDA BERBASIS ANDROID".

\section{LANDASAN TEORI}

1. Fisher-Yates Shuffle

Fisher-Yates Shuffle (dinamai berdasarkan penemunya, Ronald Fisher danFrank Yates) digunakan untuk mengubah urutan masukan yang diberikan secara acak. Permutasi yang dihasilkan oleh algoritma ini muncul dengan probabilitas yang sama. Metode dasar yang diberikan untuk menghasilkan permutasi acak dari angka 1 - $N$ berjalan sebagai berikut:

1. Tuliskan angka dari 1 sampai $n$

2. Isi nilai $\mathrm{k}$ dengan bilangan acak antara 0 hingga $i+1$ bulatkan kebawah

3. hitung dari low end, gantikan nilai $\mathrm{k}$ dan tuliskan di tempat lain

4. Ulangi dari langkah 2 sampai semua nomor digantikan

5. Urutan angka yang tertulis di langkah 3 sekarang permutasi acak dari nomor asli.

6. Pada versi yang baru (modern) angka yang terpilih tidak dicoret, tetapi ditukar posisinya dengan angka terakhir dari angka yang belum terpilih.Tabel 2.2 adalah contoh pengerjaan dari versi modern. Range adalah jumlah angka yang belum terpilih, rolladalah angka acak yang terpilih, scratch adalah daftar angka yang belum terpilih, result adalah hasil permutasi yang akan didapatkan. 
Versi modern dikenalkan karena lebih optimal dibandingkan denganversi dahulu. Prosesnyaialah angka terakhir akan dipindahkan ke angka yang ditarik keluar danmengubahangka yang ditarik keluar menjadi angka akhir yang tidak ditarik lagi untuk setiapkali penarikan dan berlanjut untuk iterasi berikutnya.

Table 1Contoh Perhitungan Algoritma Fisher

\begin{tabular}{|c|c|c|c|}
\multicolumn{5}{|c}{ Yates } \\
\hline Range & Roll & Scratch & Result \\
\hline & & 12345678 & \\
\hline $\mathbf{1 - 8}$ & 4 & 1238567 & 4 \\
\hline $\mathbf{1 - 7}$ & 3 & 127856 & 34 \\
\hline $\mathbf{1 - 6}$ & 1 & $\mathbf{6 2 7 8 5}$ & 134 \\
\hline $\mathbf{1 - 5}$ & 2 & 6578 & 2134 \\
\hline $\mathbf{1 - 4}$ & 4 & 657 & 82134 \\
\hline $\mathbf{1 - 3}$ & 1 & 75 & 682134 \\
\hline $\mathbf{1 - 2}$ & 1 & $\mathbf{5}$ & 7682134 \\
\hline & & & 57682134 \\
\hline
\end{tabular}

2. Fuzzy Tsukamoto

Ada beberapa istilah yang perlu diketahui dalam memahami sistem fuzzy, yaitu:

a. Variabel Fuzzy

Variabel fuzzy merupakan variabel yang hendak dibahas dalam suatu sistem fuzzy [20]. Contoh: Umur, Temperatur, Permintaan, Persediaan, Produksi dan sebagainya.

b. Himpunan Fuzzy

Misalkan $\mathrm{X}$ semesta pembicaraan, terdapat $\mathrm{A}$ di dalam $\mathrm{X}$ sedemikian sehingga:

$\mathrm{A}=\{\mathrm{x}, \mu \mathrm{A}[\mathrm{x}] \mid \mathrm{x} \in \mathrm{X}, \mu \mathrm{A}: \mathrm{x} \rightarrow[0,1]\}$

Suatu himpunan fuzzy A di dalam semesta pembicaraan $\mathrm{X}$ didefinisikan sebagai himpunan yang bercirikan suatu fungsi keanggotaan, yang mengawankan setiap dengan bilangan real di dalam interval, dengan nilai menyatakan derajat keanggotaan $\mathrm{x}$ di dalam A [17].

Himpunan fuzzy merupakan suatu grup yang mewakili suatu kondisi atau keadaan tertentu dalam suatu variabel fuzzy. Misalkan $\mathrm{X}=$ Umur adalah variabel fuzzy. Maka dapat didefinisikan himpunan "Muda", "Parobaya", dan "Tua" [21].

c. Semesta Pembicaraan

Semesta pembicaraan adalah keseluruhan nilai yang diperbolehkan untuk dioperasikan dalam suatu variabel fuzzy. Semesta pembicaraan merupakan himpunan bilangan real yang senantiasa naik (bertambah) secara monoton dari kiri ke kanan. Nilai semesta pembicaraan dapat berupa bilangan positif maupun negatif. Adakalanya nilai semesta pembicaraan ini tidak dibatasi batas atasnya. Contoh: semesta pembicaraan untuk variabel umur: $[0,+\infty]$ [20]. Sehingga semesta pembicaraan dari variabel umur adalah $0 \leq$ umur $<+\infty$. Dalam hal ini, yang diperbolehkan untuk dioperasikan dalam variabel umur adalah lebih besar dari atau sama dengan 0, atau kurang dari positif tak hingga.

d. Domain

Domain himpunan fuzzy adalah keseluruhan nilai yang diijinkan dalam semesta pembicaraan dan boleh dioperasikan dalam suatu himpunan fuzzy. Seperti halnya semesta pembicaraan, domain merupakan himpunan bilangan real yang senantiasa naik (bertambah) secara monoton dari kiri ke kanan. Nilai domain dapat berupa bilangan positif maupun negatif. Contoh domain himpunan fuzzy: Muda $=[0,45]$ [20].

3. Game

Game merupakan kata dalam bahasa inggris yang berarti permainan. Permainan merupakan sesuatu yang dapat dimainkan dengan aturan tertentu sehingga ada yang menang dan ada yang kalah, biasanya dalam konteks tidak serius atau dengan tujuan refreshing. Suatu cara belajar yang digunakan dalam menganalisa interaksi antara sejumlah pemain maupun perorangan yang menunjukkan strategistrategi yang rasional [6].

\section{Titi Laras}

Titilaras adalah suatu sistem dan merupakan bagian daripada ilmu karawitan yang di dalamnya terdapat ilmu menabuh, 
titilaras bertugas untuk mendokumenter lagu-lagu baik yang sudah lama maupun yang masih baru. Selain itu titilaras juga berguna dalam metoda pembelajaran karawitan, tanpa itu baik pelatih, pendidik, maupun siswa akan mendapat kesukaran didalam mempelajari karawitan.Banyak sekali sebutan-sebutan yang menunjukan wujud daripada titilaras, seperti: serat lagu, tulisan lagu, enot, enut, dsb. Istilah-istilah tersebut dapat diartikan sebagai notasi atau solmisasi atau serat kanayagan (sebutan yang diberikan oleh RMA Kusumadinata).

\section{Android}

Android adalah sebuah sistem operasi untuk perangkat mobile berbasis linux yang mencakup sistem operasi, middleware dan aplikasi. Android menyediakan platform yang terbuka bagi para pengembang untuk menciptakan aplikasi [5].

6. $\mathrm{C \#}$

C\# adalah bahasa yang dapat digunakan untuk membangun aplikasi yang akan berjalan pada .NET CLR. Bahasa ini adalah bahasa evolusi dari bahasa $\mathrm{C}$ dan $\mathrm{C}++$ dan dibuat khusus oleh Microsoft untuk bekerja pada platform .NET. Bahasa pemrograman $\mathrm{C \#}$ didesain dengan menggabungkan seluruh fitur terbaik dari bahasa pemrograman lain sembari memperbaiki masalah-masalah pada bahasa lain.

\section{ANALISIS SISTEM}

\section{Arsitektur Sistem}

Arsitektur sistem adalah istilah untuk menyatakan bagaimana mendefinisikan komponen-komponen yang lebih spesifik secara terstruktur.

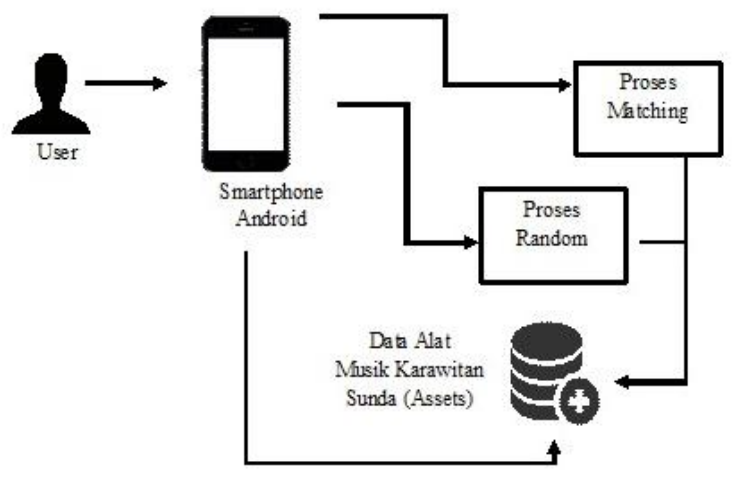

Gambar 1. Arsitektur Sistem

\section{Use Case}

Use case diagram menggambarkan fungsionalitas yang diharapkan dari sebuah sistem. Sebuah use case mempresentasikan sebuah interaksi antara aktor dengan sistem. Berikut adalah perancangan use case diagram yang diusulkan.

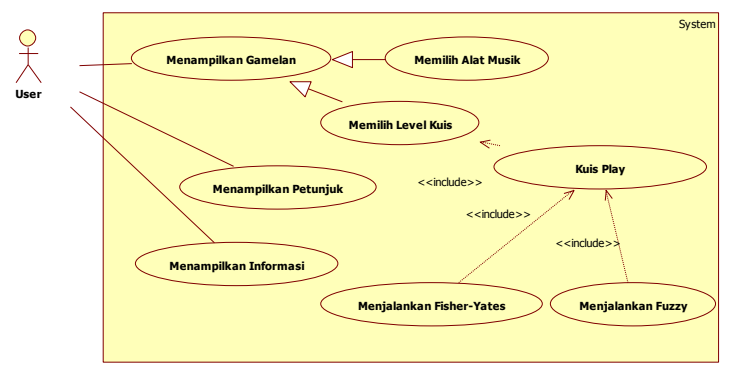

Gambar 2. Use case Diagram Tebak Nada Sunda

\section{Class Diagram}

Diagram ini memperlihatkan himpunan kelas-kelas, antarmuka-antarmuka, kolaborasi-kolaborasi, dan relasi-relasi. Diagram ini umum ditemui pada pemodelan sistem berorientasi objek. Meski sifatnya statis, sering pula memuat kelas-kelas aktif. Berikut class digram aplikasi tebak nada sunda.

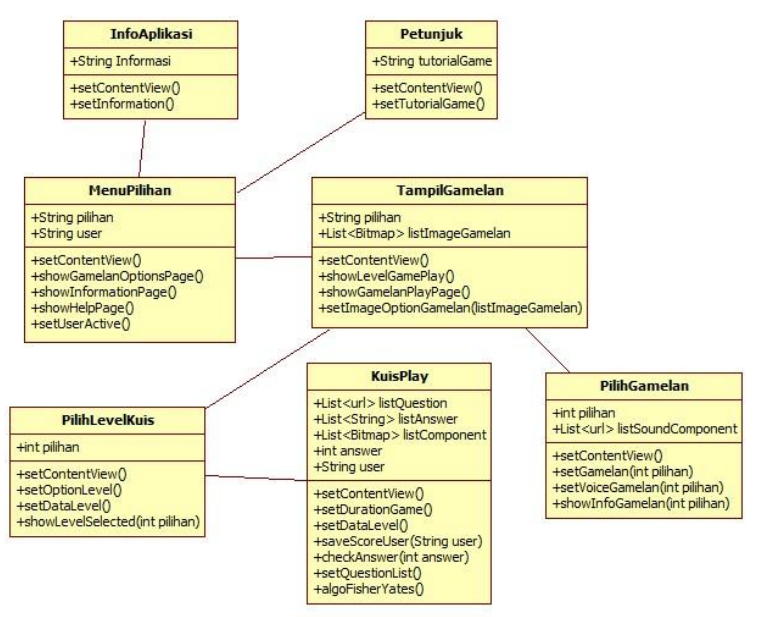

Gambar 3. Class Diagram

4. Tampilan Aplikasi
A. Tampilan Menu Utama

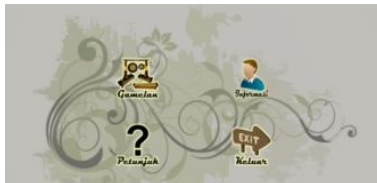

Gambar 4. Tampilan Menu Utama 
Gambar diatas merupakan tampilan menu utama, terdapat 4 menu dalam menu utama yaitu gamelan, Informasi, petunjuk dan exit.

\section{B. Tampilan Menu Gamelan}

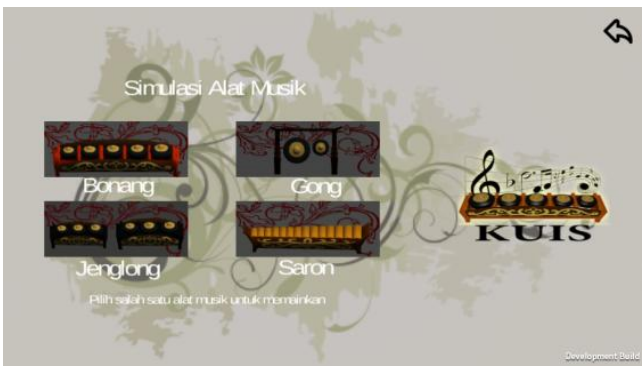

Gambar 5.Tampilan Menu Gamelan

Gambar daiatas merupakan tampilan menu gamelan, terdapat 4 menu pilihan alat music yang bisa dimainkan dan terdapat menu kuis untuk melakakun test kepekaan telinga terhadap alat musik yang sebelumnya dimainkan.

\section{Tampilan Alat Musik Bonang}

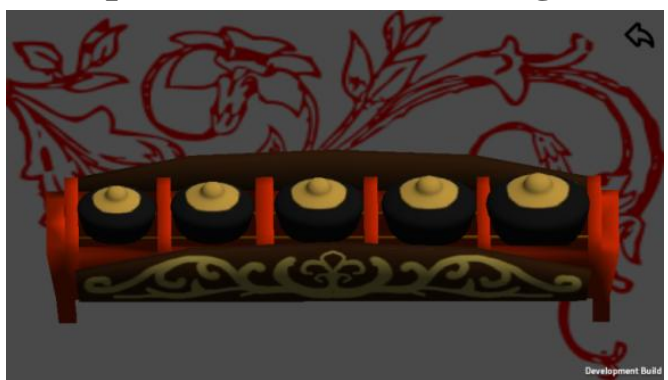

Gambar 6.Tampilan Alat Musik Bonang
D. Tampilan Alat Musik Gong

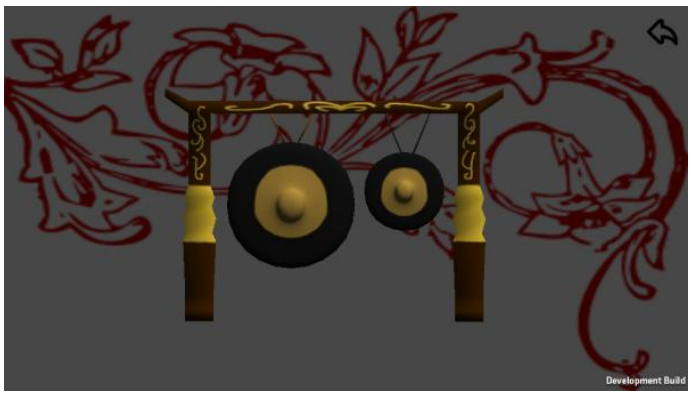

Gambar 7.Tampilan Alat Musik Gong

E. Tampilan Alat Musik Saron

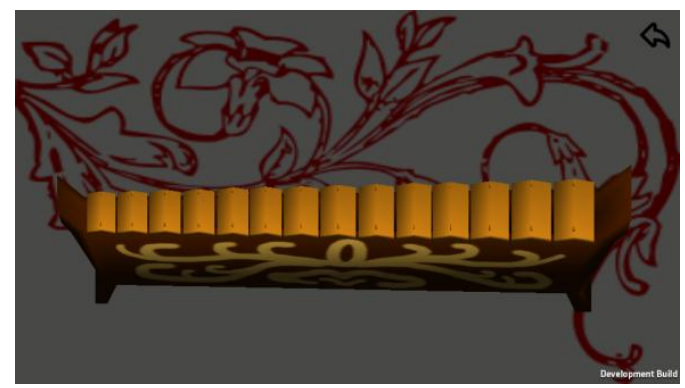

Gambar 8.Tampilan Alat Musik Saron

F. Tampilan Menu Pemilihan Level Kuis

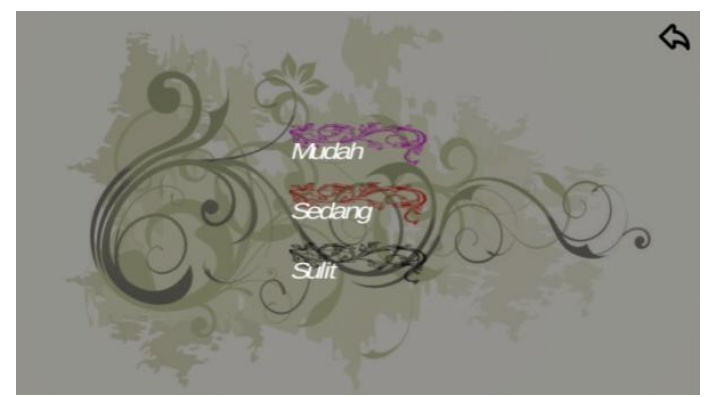

Gambar 9.Tampilan Menu Pemilihan Level

G. Tampilan Kuis Play

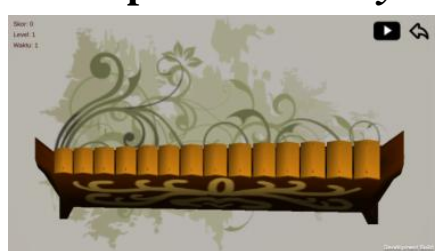

Gambar 10.Tampilan Kuis Play

H. Tampilan Menu Informasi

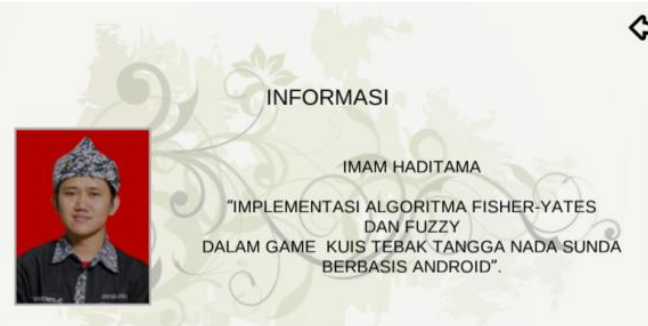

Gambar 11.Tampilan Menu Informasi Gambar diatas merupakan tampilan menu informasi, menu ini berisikan informasi pembuat aplikasi.

I. Tampilan Menu Petunjuk

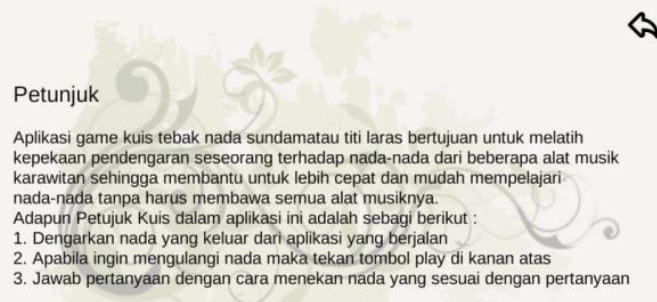

Gambar 12.Tampilan Menu Petunjuk Gambar 4.14 merupakan tampilan menu petunjuk, menu ini berisikan petunjuk penggunaan aplikasi.

IV. HASIL PENELITIAN 
Hasil penelitian dalam penelitian ini berupa akurasi pengacakan algoritma fisheryates dan akurasi perhitungan pemberian nilai akhir menggunakan fuzzy tsukamoto dengan cara membandingkan perhitungan secara manual dan perhitungan pada sistem yang berjalan.

A. Hasil pengujian Algoritma Fisher-Yates

Tabel 2. Pengujian Algoritma Fisher-Yates Shuffle pada Aplikasi

\begin{tabular}{|c|c|l|c|c|}
\hline No & Masukan & $\begin{array}{c}\text { Hasil yang } \\
\text { diharapkan }\end{array}$ & $\begin{array}{c}\text { Berh } \\
\text { asil }\end{array}$ & $\begin{array}{c}\text { Tidak } \\
\text { berha } \\
\text { sil }\end{array}$ \\
\hline 1. & $\begin{array}{c}10-20 \\
\text { kali game } \\
\text { play }\end{array}$ & $\begin{array}{l}\text { Pengacakan } \\
\text { soal dalam } \\
\text { kuis tebak } \\
\text { nada sunda }\end{array}$ & $\sqrt{ }$ & \\
\hline 2. & $\begin{array}{c}31-40 \\
\text { kali game } \\
\text { play }\end{array}$ & $\begin{array}{l}\text { Pengacakan } \\
\text { soal dalam } \\
\text { kuis tebak } \\
\text { nada sunda }\end{array}$ & $\sqrt{ }$ & \\
\hline 3. & $\begin{array}{c}\text { 41-50 } \\
\text { kali game } \\
\text { play }\end{array}$ & $\begin{array}{l}\text { Pengacakan } \\
\text { soal dalam } \\
\text { kuis tebak } \\
\text { nada sunda }\end{array}$ & $\sqrt{ }$ & \\
\hline
\end{tabular}

Dari hasil tabel diatas telah dilalukan pengijian terhadap Algoritma Fisher-Yates yang dilakukan dengan cara memainkan kuis sebanyak 50x secara terus menerus agar dapat dilihat apakah permutasi yang diterapkan dalam kuis berhasil dijalankan.

B. Hasil Pengujian Algoritma Fuzzy Tsukamoto

Tabel 3.Pengujian Algoritma Fuzzy Tsukamoto pada Aplikasi

\begin{tabular}{|c|c|c|c|c|}
\hline $\begin{array}{l}\mathrm{N} \\
\mathrm{o} .\end{array}$ & $\begin{array}{c}\text { Kasus } \\
\text { Uji }\end{array}$ & $\begin{array}{l}\text { Hasil yang } \\
\text { diharapkan }\end{array}$ & $\begin{array}{c}\text { Hasil } \\
\text { yang } \\
\text { didapatk } \\
\text { an }\end{array}$ & $\begin{array}{c}\text { Status } \\
\text { Valida } \\
\text { si }\end{array}$ \\
\hline 1. & $\begin{array}{l}\text { Pembuat } \\
\text { anAturan } \\
\text { Kombina } \\
\text { si } \\
(\text { Rule })\end{array}$ & $\begin{array}{l}\text { Sistem dapat } \\
\text { menerima } 2 \\
\text { nilai input } \\
\text { untuk } \\
\text { diproses } \\
\text { dengan } \\
\text { menggunaka } \\
\text { n Fuzzy } \\
\text { Tsukamoto. }\end{array}$ & $\begin{array}{l}\text { Skor: } 50 \\
\text { Level: } 1 \\
\text { Waktu: } 18\end{array}$ & Valid \\
\hline 2. & $\begin{array}{l}\text { Pengujia } \\
\mathrm{n} \\
\text { Verifikas } \\
\text { i Hasil }\end{array}$ & $\begin{array}{l}\text { Sistem dapat } \\
\text { menampilka } \\
\mathrm{n} \quad \text { output } \\
\text { yang sesuai } \\
\text { dengan rule } \\
\text { yang } \\
\text { dibangun }\end{array}$ & 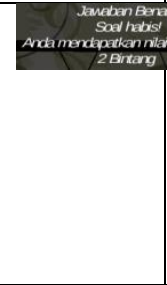 & Valid \\
\hline
\end{tabular}

Tabel 4.Pengujian Perhitungan Algoritma Fuzzy Tsukamoto pada Aplikasi

\begin{tabular}{|c|c|c|c|c|c|}
\hline \multirow{2}{*}{$\begin{array}{l}\mathrm{N} \\
\mathrm{o} .\end{array}$} & \multicolumn{2}{|c|}{ Masukan } & \multirow[b]{2}{*}{ Tujuan } & \multirow{2}{*}{$\begin{array}{c}\text { Hasil } \\
\text { Defuzzy } \\
\text { fikasi }\end{array}$} & \multirow[b]{2}{*}{ Ket } \\
\hline & $\begin{array}{l}\text { Xnil } \\
\text { ai }\end{array}$ & $\begin{array}{l}\text { Xwa } \\
\text { ktu }\end{array}$ & & & \\
\hline 1. & 90 & 24 & $\begin{array}{l}\text { Mendapatkan } \\
\text { hasil } \\
\text { perhitungan } \\
\text { hasilakhir } \\
\text { Bintang } 3\end{array}$ & 79,06 & Bintang 3 \\
\hline 2. & 50 & 18 & $\begin{array}{l}\text { Mendapatkan } \\
\text { Hasil } \\
\text { perhitungan } \\
\text { hasil akhir } \\
\text { Bintang 2 }\end{array}$ & 48,75 & Bintang 2 \\
\hline 3. & 30 & 60 & $\begin{array}{l}\text { Mendapatkan } \\
\text { Hasil } \\
\text { perhitungan } \\
\text { hasil akhir } \\
\text { Bintang 1 }\end{array}$ & 30 & Bintang 1 \\
\hline
\end{tabular}

Tabel 5.Pengujian Perhitungan Algoritma Fuzzy Secara Manual

\begin{tabular}{|c|c|c|c|c|}
\hline \multirow[b]{2}{*}{ No. } & \multicolumn{2}{|c|}{ Masukan } & \multirow[b]{2}{*}{ Defuzzyfikasi } & \multirow{2}{*}{$\begin{array}{c}\text { Hasil } \\
\text { Defuzzy } \\
\text { fikasi }\end{array}$} \\
\hline & Xnilai & $\begin{array}{c}\text { Xwakt } \\
u\end{array}$ & & \\
\hline 1. & 90 & 24 & 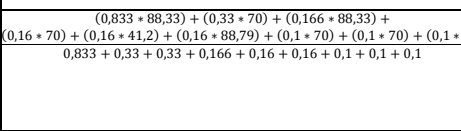 & $\begin{array}{c}73,11 \\
9820 \\
1\end{array}$ \\
\hline 2. & 50 & 18 & 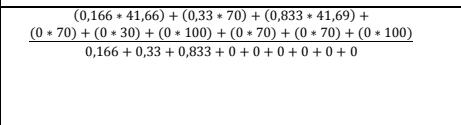 & $\begin{array}{c}48,71 \\
5823 \\
93\end{array}$ \\
\hline 3 & 30 & 60 & 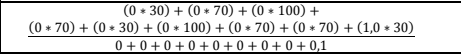 & 30 \\
\hline
\end{tabular}

Berdasarkan dari data-data diatas dapat dilihat bahwa akurasi dari perhitungan sistem dan perhitungan manual menunjukan hasil yang akurat, meskipun akurasi pada perhitungan manual dan perhitungan sistem tidak sama akan tetapi hasil menunjukkan bahawa sistem ini dapat berfungsi dengan baik dengan hasil akurasi sebesar $96.2 \%$.

\section{KESIMPULAN DAN SARAN}

\section{Kesimpulan}

Dengan adanya pembuatan aplikasi ini, kini terdapat beberapa pencapaian yang telah terpenuhi sebagai berikut:

a. Aplikasi kuis "Tebak Nada Sunda" dapat dinyatakan menarik berdasarkan hasil kuesioner yang diambil dari 40 responden secara acak sebesar $77.75 \%$ dan aplikasi ini dinyatakan userfriendly/ mudah digunakan dengan hasil kuesioner sebesar $82.25 \%$.

b. Algoritma Fisher-Yates Shuffle dapat di terapkan dalam kuis ini untuk menentukan solusi pengacakan yang tidak berganda dan pengacakan objek yang variatif berdasarkan hasil pengujian sebanyak 50x percobaan. Algoritma Fuzzy dapat diterapkan sebagai 
metode pemberian skor atau rangking pada akhir kuis. Algoritma ini memiliki akurasi yang cukup baik antara perhitungan berdasarkan sistem dan perhitungan secara manual, meskipun tidak menunjukan hasil yang $100 \%$ sama pada masing-masing perhitungan. Rentan nilai antara perhitungan sistem dengan perhitungan manual mempunyai rentan yang berbeda pada setiap nilainnya. Pada perhitungan dengan nilai Xnilai $=90$ dan Xwaktu $=24$ pada perhitungan sistem mempunyai hasil 79,06 sedangkan pada proses manual mempunyai hasil 73,1198201 sehingga pada perhitungan ini mempunyai rentang nilai sebesar 5.9401799. Pada perhitungan dengan nilai Xnilai $=50$ dan Xwaktu $=18$ pada perhitungan sistem mempunyai hasil 48,75 sedangkan pada proses manual mempunyai hasil 48,71582393 sehingga pada perhitungan ini mempunyai rentang nilai sebesar 0.03417607. Pada perhitungan dengan nilai Xnilai $=30$ dan Xwaktu $=60$ pada perhitungan sistem dan manual mempunyai nilai yang sama yaitu 30 sehingga pada perhitungan ini tidak memiliki perbedaan. Dari hasil tersebut maka di peroleh hasil akurasi perhitungan fuzzy tsukamoto sebesar 96,2\%

\section{Saran}

Untuk menambah keoptimalan aplikasi selanjutnya terdapat beberapa saran yang dapat dipertimbangkan dalam pengembangan aplikasi ini, yaitu sebagai berikut:

a. Alat musik dapat diperbanyak untuk menambah data alat musik yang dapat ditampilkan, sehingga dapat lebih menarik user dalam memainkannya;

b. Pembuatan game dengan format tiga dimensi dirasa akan memberikan visual lebih menarik bagi user, karena permainan akan lebih terasa nyata dan memberikan effect animasi menarik di dalamnya;

c. Pada proses kuis dikembangkan menjadi multiplayer agar user dapat lebih tertantang dalam menjawab soal-soal yang ada.

[1]

\section{DAFTAR PUSTAKA}

https://id.wikipedia.org/wiki/Budaya_Su nda diakses pada 27 Juni 2015.
[2] Oemar,A.Y (1985). Melestarikan Seni Budaya Tradisional yang Nyaris Punah. Bandung : Depdikbud

[3] Susanto, A., \& Honggo, H. (n.d.). Perancangan Ujian Online pada STMIK GI MDP Berbasis Webs.

[4] nazarudin safaat H. 2012. android pemrograman aplikasi mobile smarthphone dan tablet pc berbasis android

[5] Adams, Ernest. 2010. Fundamentals Of Game Design, Second Edition. Barkeley, CA : New Riders.

[6] Chandler, H., \& Rafael , C. (2011). Fundamentals of Game Development. LLC: Jones \& Barlett Learning .

[7] Munir,Rinaldi; Algoritma dan

Pemrograman dalam Bahasa Pascal dan C, Edisi Revisi, Penerbit Informatika, Bandung,

[8] Thomas H. Cormen et.al, Introduction to Algorithms Second Edition, MIT Press, McGraw-Hill Book Company, 2001

[9] T. Sutojo, S.Si., M.Kom, Edy Mulyanto, S.Si., M.Kom, Dr.Vincent Suhartono. 2007. Kecerdasan Buatan. Yogyakarta: Penerbit Andi.

[10]A.S Rosa dan Salahuddin M, 2011. Modul Pembelajaran Rekayasa Perangkat Lunak (Terstruktur dan Berorientasi Objek), Modula, Bandung.

[11]Hofstetter, Fred T. Multimedia Literacy Third Edition, New York : McGraw-Hill. 2001.

[12]Reto Meier, Profesional Android Application Development, Wiley Publishing, Canada, 2009

[13]Kim, AeHyun. 2014. Development Of Mobile Game Using Multiplatform (Unity3D) Game Engine. Department Of Industrial Design, Dong-A University, Volume 5 Number 1:29-36.

[14] https://msdn.microsoft.com/en-

us/library/hh145616(VS.88).aspx diakses pada 27 Juni 2015.

[15]Sugiarti, Yuni. 2013. Analisis dan Perancangan UML (Unified Modelling Language) Generated VB.6 Disertai Contoh Studi Kasus dan Interface Web. Yogyakarta: Graha Ilmu. 
[16]Fadholi, M Aprilian. 2014. Tes Ujian Masuk Peserta Didik Baru Menggunakan Shuffling Algorithms di Madrasah Aliyah Negeri 1 Boyolali. Skripsi S1. Yogyakarta: Universitas Islam Negeri Sunan Kalijaga.

[17] Ginanjar Abdurahman. 2011. Penerapan Metode Tsukamoto (Logika Fuzzy) Dalam Sistem Pendukung Keputusan untuk Menentukan Jumlah Produksi Barang Berdasarkan Data Persediaan dan Jumlah Permintaan. Skripsi S1. Yogyakarta: Universitas Negeri Yogyakarta.

[18] Setiadji. 2009. Himpunan \& Logika Samar serta Aplikasinya. Yogyakarta: Graha Ilmu.

[19] Nguyen, Hung T, et al. 2003. A First Course in Fuzzy and Neural Control. USA: Chapman \& Hall/CRC.

[20] Sri Kusumadewi \& Hari Purnomo. 2004. Aplikasi Logika Fuzzy Untuk Sistem Pendukung Keputusan Edisi Pertama.Yogyakarta: Graha Ilmu.

[21]Jang, J.S.R. et al. 1997. Neoro-Fuzzy and Soft Computing. London: Prentice Hall.

[22]Lin, Chin Teng \& Lee, GS George. 1996. Neural Fuzzy Systems. London: Prentice Hall.

[23] Turban, E, Aronson, Jay E \& Liang, TengPing. 2005. Decission Support Systems and Intelligent Systems Edisi 7 Jilid 2. Yogyakarta: Andi.

[24] Sri Kusumadewi \& Sri Hartati. 2006. Neuro Fuzzy-Integrasi Sistem Fuzzy dan Jaringan Syaraf. Yogyakarta: Graha Ilmu.

[25] Muhamad ilham. 2013. Pembangunan Game Edukasi Adventure Untuk Pengenalan Teori Musik Berbasis Dekstop.

http://elib.unikom.ac.id/gdl.php?mod=bro wse\&op=read\&id=jbptunikompp-gdlmuhammadil-31176\&q=ear\%20training. Tanggal Akses: 24 Februari 2016 